\title{
Bacterial DNA repair genes and their eukaryotic homologues: 3. AlkB dioxygenase and Ada methyltransferase in the direct repair of alkylated $\mathrm{DNA}^{\star}$
}

\author{
Jadwiga Nieminuszczy and Elżbieta Grzesiuk ${ }^{凶}$ \\ Department of Molecular Biology, Institute of Biochemistry and Biophysics, Polish Academy of Sciences, \\ Warszawa, Poland
}

Received: 13 April, 2007; revised: 01 June, 2007; accepted: 21 June, 2007

available on-line: 06 September, 2007

\begin{abstract}
Environmental and endogenous alkylating agents generate cytotoxic and mutagenic lesions in DNA. Exposure of prokaryotic cells to sublethal doses of DNA alkylating agents induces so called adaptive response (Ada response) involving the expression of a set of genes which allows the cells to tolerate the toxic and mutagenic action of such agents. The Ada response includes the expression of four genes: $a d a, a l k A, a l k B$, and aidB. The product of ada gene, Ada protein, is an activator of transcription of all four genes. DNA bases damaged by alkylation are removed by distinct strategies. The most toxic lesion $3 \mathrm{meA}$ is removed by specific DNA glycosylase initiating base excising repair. The toxic and mutagenic $\mathrm{O}^{6} \mathrm{meG}$ is repaired directly by methyltransferases. $1 \mathrm{meA}$ and $3 \mathrm{meC}$ are corrected by AlkB DNA dioxygenase. The mechanisms of action of E. coli

AlkB dioxygenase and its human homologs $\mathrm{ABH} 2$ and $\mathrm{ABH} 3$ are described in more details.
\end{abstract}

Keywords: alkylating agents, adaptive response, DNA repair, AlkB

\section{INTRODUCTION}

The DNA of all living organisms is constantly exposed to a number of exogenous (chemicals, radiation) and endogenous (side products of cellular metabolism) agents causing a variety of harmful lesions. To maintain DNA integrity, cells possess several defense systems that act at different levels to repair the damage (for more details see accompanying reviews by Arczewska \& Kusmierek, 2007; Maddukuri et al., 2007; Krwawicz et al., 2007; Nowosielska et al., 2007). Some lesions cause cell cycle arrest allowing DNA repair prior to replication. Based on their cellular conse- quences, damaged bases may be cytotoxic, mutagenic or both. Cytotoxic lesions block replication leading to cell death while mutagenic lesions are miscoding and cause mutations in newly synthesized DNA. Mutations resulting from miscoding are thought to be a major mechanism of carcinogenesis. Cytotoxic lesions, when bypassed by low fidelity polymerase are a source of mutations and become mutagenic.

Alkylating agents are potentially cytotoxic and mutagenic chemicals whose action induces several DNA repair systems in the cell. The cellular recovery from alkylation damage involves adaptive response, a part of which is induction of AlkB protein.

\footnotetext{
^ This paper is dedicated to our mentors: David Shugar, Celina Janion, Irena Pietrzykowska, Zofia Zarębska and Daniela Barszcz, scientists from the Institute of Biochemistry and Biophysics Polish Academy of Sciences, who contributed to a great extent to the development in the field of DNA damage, mutagenesis and repair.

$\square$ Corresponding author: E. Grzesiuk, Institute of Biochemistry and Biophysics, Polish Academy of Sciences, Pawińskiego 5a, 02-106 Warsaw, Poland; phone: (48 22) 592 3337; fax: (48 22) 658 4636; e-mail: elag@ibb.waw.pl.

Abbreviations: 3meA, 3-methyladenine; AGT, O6 meG-DNAmethyltransferase; BCNU, N,N'-bis[2-chloroethyl]- $N$-nitrosourea (carmustine); CCNU, $N$-(2-chloroethyl)- $N$ '-cyclohexyl- $N$-nitrosourea (lomustine); HTH, helix-turn-helix; MeI, methyl iodide; MMR, mismatch repair system; MMS, methyl methanesulfonate; MNNG, $N$-methyl- $N^{\prime}$-nitro- $N$-nitrosoguanidine; MNU, N-methyl-N-nitrosourea ; NNAL, 4-(methylnitrosoamino)-1-(3-pirydyl)-1-butanol; NNK, 4-(methylnitrosoamino)-1(3-pyridyl)-1-butanone; $\mathrm{NNN}, \mathrm{N}^{\prime}$-nitrosonornicotine; $\mathrm{O}^{6} \mathrm{meG}, \mathrm{O}^{6-}$ methylguanine; $\mathrm{SAM}$, S-adenosylmethionine.
} 


\section{ALKYLATING AGENTS}

The alkylating agents comprise a group of mutagens and carcinogens that modify DNA by alkylation. It is now evident that some alkylating agents are not only widespread in the environment but are also produced intracellularly (endogenously) as byproducts of normal metabolism. Alkyl base lesions can arrest replication, interrupt transcription, or signal the activation of cell-cycle checkpoints or apoptosis. In mammals they could be involved in carcinogenesis, neurodegenerative disease and aging.

Alkylating agents can introduce methyl or ethyl groups at all of the available nitrogen and oxygen atoms in DNA bases, producing a number of lesions (Fig. 1). The majority of evidence indicates that among the 11 identified base modification two, 3-methyladenine (3meA) and $\mathrm{O}^{6}$-methylguanine $\left(\mathrm{O}^{6} \mathrm{meG}\right)$, are mainly responsible for the biological effects of alkylation agents (Singer, 1976). Contribution of various lesions depends on the type of agent, its reaction mechanism and the secondary structure of the DNA target. Based on the reaction mechanism used, alkylating agents can be divided into two subgroups (Fig. 2). The $S_{N} 1$ reagents, such as $\mathrm{N}$-methyl- $\mathrm{N}$-nitrosourea (MNU) and $\mathrm{N}$-methyl$N^{\prime}$-nitro- $N$-nitrosoguanidine (MNNG) use a monomolecular mechanism, while the $\mathrm{S}_{\mathrm{N}} 2$ ones, that include methyl methanesulfonate (MMS) and methyl iodide (MeI), act by a bimolecular mechanism. The $\mathrm{S}_{\mathrm{N}} 1$ type agents introduce alkyl adducts both at $\mathrm{N}$ and $\mathrm{O}$ atoms; in the case of the $\mathrm{S}_{\mathrm{N}} 2$ subgroup, $\mathrm{N}$ alkylation prevails. The major base modifications introduced in doubled stranded DNA by methylating agents are: $7 \mathrm{meG}, 3 \mathrm{meA}, \mathrm{O}^{6} \mathrm{meG}$, while $1 \mathrm{meA}$, $3 \mathrm{meC}, 7 \mathrm{meA}$, and $\mathrm{O}^{4} \mathrm{meT}$ represent minor modifications. In single stranded DNA $1 \mathrm{meA}$ and $3 \mathrm{meC}$ are more frequent than in dsDNA. The most mutagenic adduct introduced into DNA by methylating agents is $\mathrm{O}^{6} \mathrm{meG}$. This modification mispairs during replication with thymine leading to $\mathrm{GC} \rightarrow \mathrm{AT}$ transition in dsDNA. N1 in adenine and N3 in cytosine are involved in Watson-Crick base pairing and in this way are protected from modifications (Falnes \& Rognes, 2003).

As already mentioned alkylating agents are present in the environment but also occur endogenously in all cells. One of the central molecules in metabolism is $S$-adenosylmethionine (SAM), a principal biological methyl donor, and precursor of aminopropyl groups utilized in polyamine biosynthesis, and, in the liver, glutathione through its conversion to cysteine $(\mathrm{Lu}, 2000)$. Since methylation plays a critical role in cellular processes such as gene expression and membrane fluidity, any alterations in SAM concentration may affect cell functioning. Abnormalities in SAM metabolism are especially connected with liver diseases, some neurological disorders and spontaneous carcinogenesis (Lutz, 1990).

SAM can spontaneously methylate DNA. It acts by an $\mathrm{S}_{\mathrm{N}} 2$ mechanism and generates mainly $7 \mathrm{meG}$ and $3 \mathrm{meA}$ and, to a lesser extent, $\mathrm{O}^{6} \mathrm{meG}$. Its reactivity, however, is about 2000-fold weaker than that of MMS (Rydberg \& Lindahl, 1982), nevertheless it is capable of acting as a carcinogen in vivo (Barrows \& Magee, 1982). Apart from SAM, lipid peroxidation and amine nitrosation comprise other internal sources of alkyl group. Several N-alkyl-Nnitrosocompounds (e.g. methylnitrosourea) are generated by nitrosation of glycine and its derivatives (Shuker \& Margison, 1997; Garcia-Santos Mdel et al., 2001). In Escherichia coli strains mutated in both known genes encoding $\mathrm{O}^{6}$-alkylguanine-DNA alkyltransferase an elevated level of spontaneous mutations is observed.

The most abundant environmental alkylating agents are chloromethane and other halocarbons. Methyl chloride $(\mathrm{MeCl})$ is generated in many terrestrial environments by abiotic conversion of chloride. In plants, pectin is a donor of methyl group (Hamilton et al., 2003). In some algae and fungi living in a saline environment $\mathrm{MeCl}$ is also generated as a product of chloride detoxification (Sedgwick \& Vaughan, 1991). Bromomethane occurs naturally in the ocean. Halohydrocarbons are also generated by anthropogenic sources and contribute to stratospheric ozone depletion (Goodwin et al., 2005).

The N-nitroso compounds formed in tobacco smoke are recognized as one of the most important environmental alkylating agents influencing health of the persons exposed. The most carcinogenic among
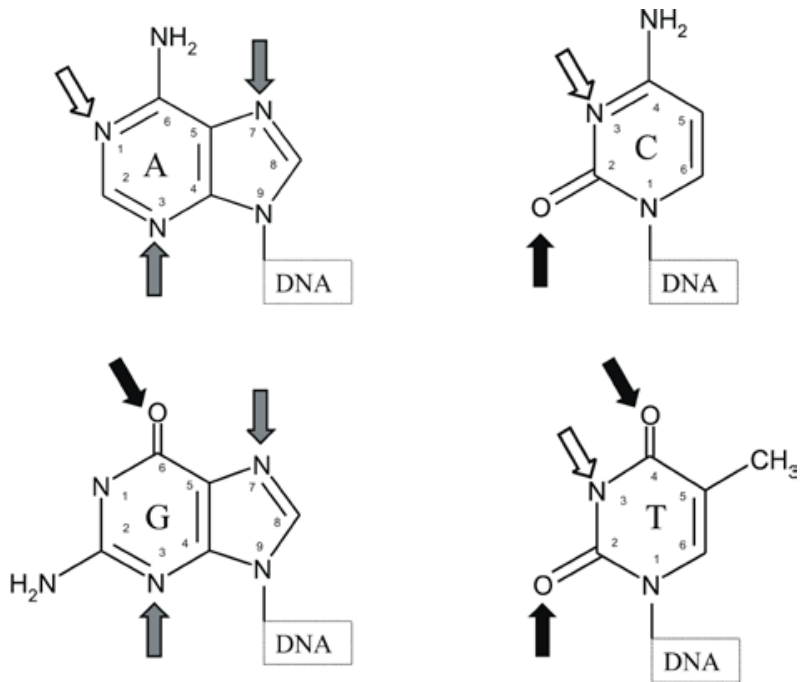

Figure 1. Possible sites of alkylation of DNA bases.

Grey arrows indicate sites alkylated by most of the agents; black arrows - sites that are most frequent alkylated by $\mathrm{S}_{\mathrm{N}} 1$ agents; white arrows - sites alkylated by $\mathrm{S}_{\mathrm{N}} 2$ agents in single-stranded DNA. 

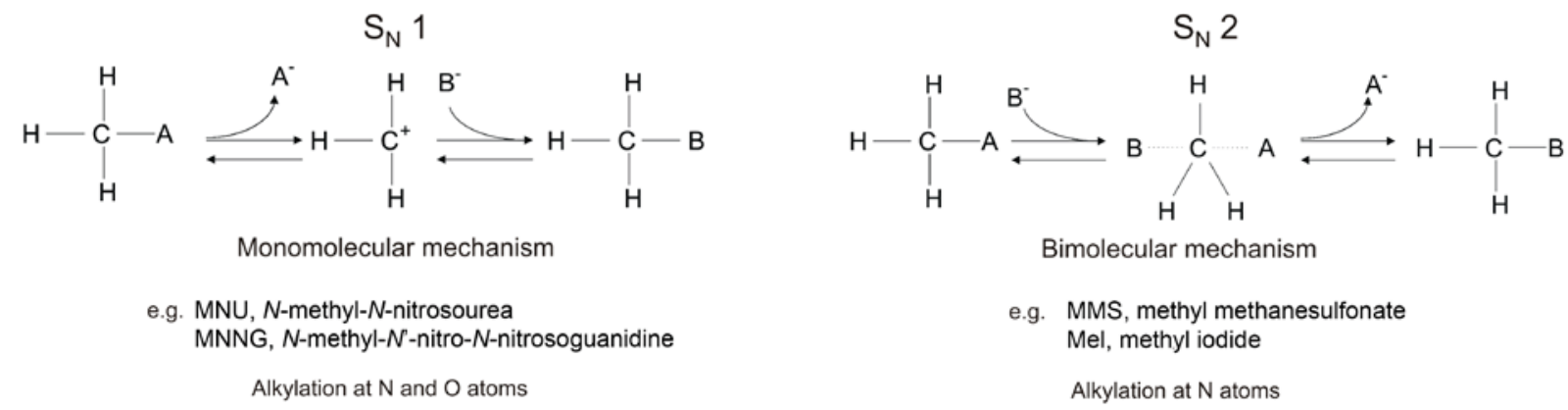

Figure 2. Two types of nucleophilic substitutions $-S_{N} 1$ and $S_{N} 2$.

Electron-rich nucleophile (B) attacks a molecule and replaces a departing group (A). During DNA base alkylation the source of the nucleophile is the base and the leaving anion is generated by the alkylating agent.

the tobacco-specific nitrosamines are 4-(methylnitrosoamino)-1-(3-pyridyl)-1-butanone (NNK), 4-(methylnitrosoamino)-1-(3-pirydyl)-1-butanol (NNAL), and $N^{\prime}$-nitrosonornicotine (NNN) (Hecht, 2002).

One of the tobacco alkaloids, myosamine, is also present in a variety of foodstuffs, including fruits, vegetables and even milk. It is easily nitrosated to DNA-alkylating compounds, including NNN (Drablos et al., 2004). Myosamine has been detected in maize, rice, wheat flour, millet, potato, and milk, also in cocoa, popcorn, tomato, carrot, pineapple, kiwi, and apples but not in other vegetables and fruits such as lettuce, spinach, cucumber, onion, banana, tangerines, or grapes. This dietary myosamine could be involved in esophageal carcinogenesis (Tyroller et al., 2002).

Taking under consideration the cytotoxic effects of many alkylating agents, they have been considered as anti-cancer drugs (Chaney \& Sancar, 1996, Hurley, 2002). In therapy mainly methylating (e.g., temozolomide and streptosotocin) and chloroethylating agents (e.g., chloroethylnitrosoureas, CENUs: carmustine, lomustine and fotemustine) are used. The most important target of their activity is the $\mathrm{O}^{6}$ position of guanine but they introduce alkyl adducts at other positions also. CENUs show a wide spectrum of activity. They have been used in Hodgkin's disease, non-Hodgkin's lymphoma, multiple myeloma, and melanoma and because of their ability to cross the blood-brain barrier, also in the treatment of primary brain tumors (Chaney \& Sancar, 1996).

The repair of damage to DNA caused by alkylating agents involves at least four different mechanisms: (i) lesions can be repaired directly by methyltransferases or oxidative demethylases; (ii) with the use of base excision repair initiated by DNA glycosylases; (iii) by mismatch repair system; and (iv) by nucleotide excision repair. Within the systems protecting cells against the action of alkylating agents in E. coli there is the adaptive response to DNA damage.
The strong conservation of the system indicates the evolutionary importance of alkylated-DNA repair.

\section{Ada PROTEIN}

To overcome the mutagenic and cytotoxic effects caused by alkylating agents, cells possess a mechanism of adaptation induced after exposure to small doses of such reagents. This adaptive response to alkylating agents (Ada response) has been most extensively studied in E. coli. It is widely accepted that induction of Ada response results in an increased expression of four genes: ada, alkB, alkA and aidB (Lindahl et al., 1988) A key component of this response is the Ada protein, a multifunctional molecule showing $\mathrm{O}^{4} \mathrm{meT}$ and $\mathrm{O}^{6} \mathrm{meG}$ methyltransferase activity and functioning as an activator of transcription of its own gene as well as those encoding AlkA AlkB, and AidB (Lindahl et al., 1988; Teo et al., 1984) (Fig. 3). The product of the alkA gene shows a DNA glycosylase activity with broad substrate specificity (for review see J. Krwawicz, this issue). The AidB protein has been supposed to take part in the degradation of endogenous alkylating agents (Landini et al., 1994). It shows some homology to acyl-CoA oxidases and those containing flavins (Landini et al., 1994; Rohankhedkar et al., 2006). Recent observations suggest that AidB may bind to double-stranded DNA and take part in its dealkylation (Rohankhedkar et al., 2006). However, to determine the precise function of AidB further investigations are necessary.

The $39 \mathrm{kDa}$ Ada protein is composed of two major domains, a $19 \mathrm{kDa}$ C-terminal (C-Ada19) and a $20 \mathrm{kDa}$ N-terminal (N-Ada20) one, linked by a hinge region susceptible to proteolytic cleavage. These domains can function independently. C-Ada19 transfers methyl adducts from $\mathrm{O}^{6} \mathrm{meG}$ and $\mathrm{O}^{4} \mathrm{meG}$ onto its Cys-321 residue, whereas N-Ada20 demethylates $S_{p}$-diastereoisomers of methylphosphotriesters 


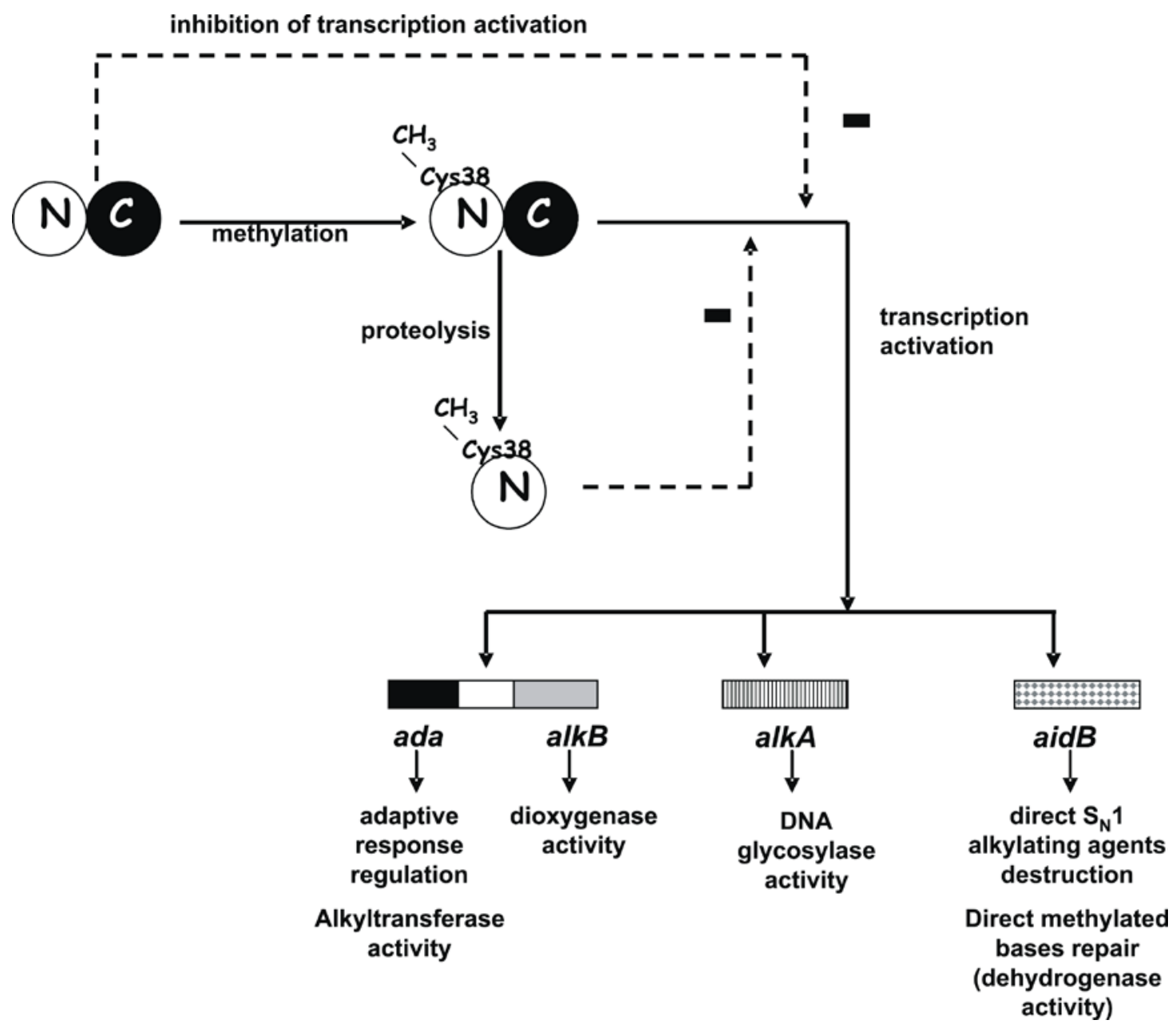

Figure 3. Adaptive response regulation.

Ada protein is activated as a transcription factor by methylation of its Cys-38 that occurs by repair of methylphosphotriesters or by direct protein methylation. $(\mathrm{N})$ - N-terminal part of Ada protein; $(\mathrm{C})$ - C-terminal part of Ada protein.

by methyl transfer onto Cys-38 (Kondo et al., 1986; Sedgwick et al., 1988; Lindahl et al., 1988; Moore et al., 1994; He \& Verdine, 2002, He et al., 2003).

The N-terminal domain possesses a high-affinity $\mathrm{Zn}^{2+}$ binding site. The metal ion is probably coordinated by the motif Cys- $\mathrm{X}_{3}-\mathrm{Cys}-\mathrm{X}_{26}-\mathrm{Cys}-\mathrm{X}_{2}-$ Cys. Cysteines building this motif are Cys38 (methyl acceptor), Cys42, Cys69 and Cys72. The existence of a (Cys) $)_{4}$ zinc-binding element suggests a structural and evolutionary relation of E. coli Ada protein to some $\mathrm{Zn}$-finger transcription factors of higher organisms (Myers et al., 1992).

The $39 \mathrm{kDa}$ Ada protein activates transcription of the Ada regulon genes in two different ways (Fig. 3). In the case of the ada-alkB operon and aidB promoter, for transcription activation N-Ada20 domain interacts with the $\alpha$ subunit of RNA polymerase and C-Ada19 with $\delta$ subunit. Although these interactions are independent, both are necessary for transcription activation. For activation of alkA gene, the N-Ada20 domain interacts with the $\alpha$ and $\delta$ subunits of RNA polymerase, however, only the Nterminal domain of Ada is required and methylation of Cys-38 is probably not necessary. Cys-38 can be methylated by $\mathrm{SN}_{2}$ agents directly, which may be an alternative but less effective way of Ada activation (Landini \& Volkert, 2000).

C-Ada19 repairs $\mathrm{O}^{6} \mathrm{meG}$ and $\mathrm{O}^{4} \mathrm{meT}$ by transferring methyl moiety onto its own Cys-321 similarly as N-Ada20 onto its Cys-38. Methylation of Cys-321 is irreversible so the action of the enzyme is suicidal. Crystal structure studies have revealed two structurally distinct regions within C-Ada19. The $\mathrm{N}$-terminal region shows similarity to RNase $\mathrm{H}$ structure, whereas the C-terminus forms predominantly $\alpha$-helices and connecting loops (Katayanagi et al., 1990; Yang et al., 1990). Three helices within this region bear a strong resemblance to the helix-turnhelix (HTH) motif. The putative DNA binding helix is far away from the active Cys-321 so probably the 
HTH motif is involved in general binding to DNA. Surprisingly, the active site thiol of the Cys residue in the Pro-Cys-His-Arg active site is buried in the structure of C-Ada19. A conformational change, therefore, is indispensable for this cysteine to carry out a nucleophilic attack on the target methyl group (Moore et al., 1994). One model suggests a rotation of the most of C-terminal helix exposing a DNAbinding surface of the protein, making Cys-321 available to the substrate. On the other hand, the second helix of the HTH motif implicated in DNA binding contains a conserved $\operatorname{RAV}(\mathrm{A}, \mathrm{G})$ sequence called "arginine-finger" that promotes base flipping of the substrate nucleotide from DNA (Daniels et al., 2000, Daniels \& Tainer, 2000; Wibley et al., 2000).

The Ada $39 \mathrm{kDa}$ protein alkylation is irreversible, so the question concerning the mechanism of the Ada response termination remains open. It has been postulated that the activated Ada protein is simply diluted by cell division after withdrawal of alkylating agents (Lindahl et al., 1988). A second hypothesis indicates a possible role of the $20 \mathrm{kDa}$ Nterminal product of Ada protein proteolysis in inhibition of the Ada-regulated gene transcription (Teo et al., 1984; Lindahl et al., 1988). Yet another possibility is that unmethylated Ada, when all repairable methylphosphotriesters have been repaired, shuts off the adaptive response by accumulation in the cell and competition with the methylated protein for binding to the regulated genes (Saget \& Walker, 1994).

Under normal conditions, there are about two molecules of Ada protein per E. coli cell. Induction of the Ada response increases the level of Ada to about 3000 molecules per cell. The observation that some alkyltransferase activity is still present in an E. coli mutant with an ada gene deletion suggests the presence of another alkyltransferase in E. coli (Rebeck et al., 1988; Shevell et al., 1988). Indeed, the second alkyltransferase has been identified as the constitutively expressed Ogt protein, product of the ogt gene. The $19 \mathrm{kDa}$ Ogt protein repairs $\mathrm{O}^{6} \mathrm{meG}$ and $\mathrm{O}^{4} \mathrm{meT}$. It shows a similar activity as the C-Ada19 domain. The amino-acid sequence also shows some homology to the region containing Cys-321 (Potter et al., 1987).

AGT activity has been detected in many organisms (e.g., the yeast Saccharomyces cerevisie, the filamentous fungus Aspergillus nidulans, the nematode Caenorhabditis elegans, the fruit fly Drosophila melanogaster) and also in fish and mammalian cells (Friedberg, 2006).

In human cells the alkyltransferase activity is the product of the MGMT gene (Harris et al., 1983; Kataoka et al., 1986). The $21.7 \mathrm{kDa}$ MGMT protein is built of amino-acid sequences very similar to those of both E. coli alkyltransferases, Ada and Ogt. In contrast to the bacterial enzymes it mainly repairs
$\mathrm{O}^{6} \mathrm{meG}$, whereas removal of the alkyl adduct from $\mathrm{O}^{4} \mathrm{meT}$ is much slower and significantly less effective (Brennand \& Margison, 1986; Koike et al., 1990). The preferential repair of $\mathrm{O}^{6} \mathrm{meG}$ is profitable for eukaryotic cells since in experimental animals treated with alkylating carcinogens this lesion is involved in tumor stimulation. Alkylating agents producing a small amount of $\mathrm{O}^{6} \mathrm{meG}$ are weak carcinogens.

Expression of MGMT prevents cancer development associated with exposure to alkylating agents. Many animal studies have shown that overexpression of MGMT gene suppresses alkylationinduced carcinogenesis, e.g. MNU-induced thymic lymphomas, MNNG-induced skin cancer, dimethylnitrosamine-induced liver tumors (Dumenco et al., 1993; Nakatsuru et al., 1993; Becker et al., 1996). Also, a low AGT activity predisposes to alkylationinduced tumorigenesis especially leading to lymphomas and breast, lung and colon cancers. These data suggest that human tissues with a low AGT level are more sensitive to carcinogenesis developed by environmental agents.

On the other hand alkylating agents are often used in cancer treatment. Many of them attack the $\mathrm{O}^{6}$ position of guanine. There are two major groups of such agents, chloroethylating and methylating ones. Carmustine (BCNU) and lomustine (CCNU) belong to the first group. They generate $\mathrm{N}^{1}-\mathrm{O}^{6}$-ethanoguanine leading then to a crosslink with the opposite-strand cytosine (Tong et al., 1982). The G-C inter-strand crosslink leads to replication inhibition and induction of p53 and p21, proteins acting against carcinogenesis through positive regulation of apoptosis (Gerson, 2002).

The group of methylating agents is represented by, e.g., procarbazine, temozolomide, streptozotocin, dacarbazine. During replication they form $\mathrm{O}^{6} \mathrm{meG}$ causing incorrect incorporation of thymine into the newly synthesized strand. This mispair is recognized by the mismatch repair system (MMR) and, especially when there is another $\mathrm{O}^{6} \mathrm{meG}$ in the template DNA strand, their repair may lead to single and double strand breaks, sister chromatid exchanges, and even chromosomal aberrations. Since MMR preferentially repairs the newly synthesized strand, the alkyl lesion in the template strand may remain and start the whole MMR process again, thus effectively inducing apoptosis (Hickman \& Samson, 1999).

Dysfunction of the MMR system makes cells more tolerant of lesions in DNA caused by methylating agents. However, the most important factor determining the resistance of tumor cells to alkylating anti-cancer drugs is AGT alkyltransferase. There is a strong correlation between MGMT gene expression and the cell survival of treatment with $\mathrm{O}^{6}$-alkylating agents (Gerson, 2002). 
In many cases modulation of AGT activity seems to be of great importance for anti-cancer therapy. Efforts to improve effectiveness of the therapy include the sequential administration of alkylating agent (depleting MGMT) or MGMT inhibitors, e.g. $\mathrm{O}^{6}$-benzylguanine or $\mathrm{O}^{6}$-(4-bromothenyl) guanine (Middleton et al., 2000). On the other hand, bone marrow cells show high sensitivity to alkylating anti-cancer drugs especially when these are used in combination with MGMT inhibitors. The solution of this problem connected with the use of alkylating agents in anti-cancer chemotherapy is perceived in the protection of bone marrow cells by selective expression of MGMT (Gerson, 2002).

\section{AlkB DIOXYGENASE AND ITS HUMAN HOMOLOGS}

The alkB gene is part of the ada regulon inducible during the adaptive response. Despite the isolation of an E. coli strain defective in alkB function as early as 1983, the nature and function of the alkB gene were unknown for many years (Kataoka et al., 1983). First, it was discovered that the alkB gene product, AlkB protein, acts alone and when expressed in human cells it is able to confer resistance of them to alkylating agents (Chen et al., 1994). Later it was found that human homolog of the bacterial gene gives partial resistance of the E. coli alk $B^{-}$mutant to the methylating agent MMS (Wei et al., 1996).

The observation that single-stranded phages are more sensitive to certain alkylating agents while growing in E. coli alkB $B^{-}$cells has suggested that AlkB repairs lesions generated by $S_{N} 2$ methylating agents specifically in single-stranded, but not in doublestranded DNA (Dinglay et al., 2000). These data suggested that $1 \mathrm{meA}$ and $3 \mathrm{meC}$ can be substrates for AlkB protein, since the ring nitrogens at these positions are protected by hydrogen bond formation in duplex DNA (Lawley \& Brookes, 1963; Bodell \& Singer, 1979). Also, a bioinformatic analysis of predicted protein folding has led to the insightful conclusion that AlkB is a member of the $\alpha$-ketoglutarate- $\mathrm{Fe}^{2+}$-dependent-dioxygenase superfamily (Aravind \& Koonin, 2001). These non-heme iron enzymes require $\mathrm{Fe}^{2+}$ as a cofactor, and $\alpha$-ketoglutarate and dioxygen as co-substrates (Fig. 4). They catalyze the hydroxylation of a hydrocarbon bond in the substrate coupled to the oxidative decarboxylation of $\alpha$-ketoglutarate producing succinate and $\mathrm{CO}_{2}$. One atom of oxygen from $\mathrm{O}_{2}$ is incorporated as a hydroxyl in the substrate, the other in the carboxylate group of succinate. It is accepted that dioxygenases catalyze a variety of reactions (hydroxylations, ring desaturation, and oxidative ring closures) among

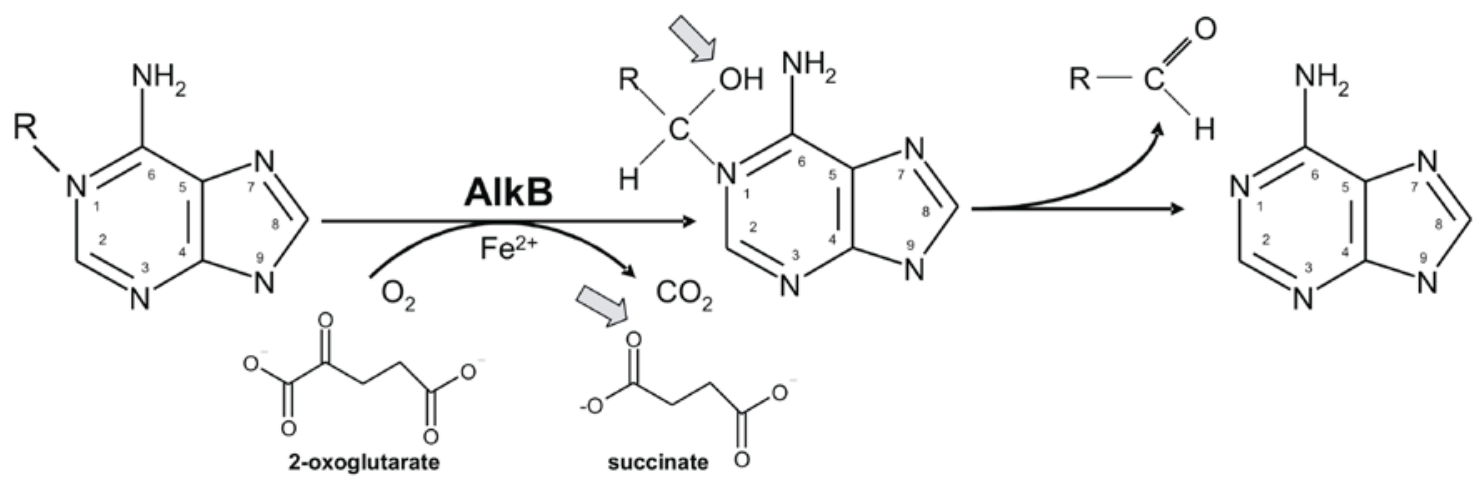

SUBSTRATE

1-methyladenine
HYDROXYLATED INTERMEDIATE
PRODUCTS

adenine + formaldehyde

adenine + acetaldehyde

Figure 4. Mechanism of alkylated DNA repair by AlkB protein.

Grey arrows indicate oxygen atoms originated from oxygen molecule. The lower part of the figure shows examples of possible substrates, intermediates and products of AlkB-catalyzed reaction. 
which participation in the oxidation of proline in collagen, the biosynthesis of some antibiotics, and biodegradation of various ring compounds are of general importance (Aravind \& Koonin, 2001).

In 2002 two independent groups confirmed experimentally the participation of AlkB in DNA repair (Falnes et al., 2002; Trewick et al., 2002). It has been found that AlkB using the dioxygenase mechanism, when supplied with $\alpha$-ketoglutarate and $\mathrm{Fe}^{2+}$, reverts $1 \mathrm{meA}$ and $3 \mathrm{meC}$ in DNA directly to adenine and cytosine with the release of the oxidized methyl group as formaldehyde. The intermediate products are 1-hydroxymethyladenine and 3-hydroxymethylcytosine, both expected to be unstable and to decompose releasing formaldehyde.

Further studies have shown that trinucleotides and even methylated dAMP are recognized by AlkB as substrates. Also 1-methyldeoxyguanosine and 3methylthymine are repaired by this $E$. coli protein. However, the repair of these lesions is significantly slower than that of $1 \mathrm{meA}$ and $3 \mathrm{meC}$, suggesting that in vivo it is inefficient. An ability of AlkB to remove larger adducts like ethyl, hydroxyethyl, propyl, and hydroxypropyl has also been observed (Koivisto et al., 2003).

Recent studies have shown that apart from alkylated substrates, AlkB also restores adenine and cytosine from cadenine and $1, N^{6}$-ethenocytosine. In this case the protein acts according to a distinct chemical mechanism of direct reversal, namely, epoxidation of the double bond of the etheno adduct resulting in the release of glyoxal and the undamaged base (Delaney et al., 2005; Mishina et al., 2005). Recent findings of the Essigmann's group indicate the ability of AlkB to repair ethanoadenine (Frick et al., 2007). Ethano adducts are formed in DNA by the anticancer chemotherapeutic agent BCNU.

The first human homolog of the E. coli AlkB protein, hABH1 was found in 1996 (Wei et al., 1996). Two others, hABH2 and hABH3, were identified by computer analysis and functional complementation (Duncan et al., 2002; Aas et al., 2003). An in silico analysis found another five alkB homologs, hABH4hABH8 (Kurowski et al., 2003). Although all these proteins share the motifs and residues essential for enzymatic activity (the HXD motif, single $\mathrm{H}$, and the RXXXXXR motif) until now only hABH2 and hABH3 have shown a similar activity as bacterial AlkB protein. The mentioned motifs occur as follows: $\mathbf{H}_{131} \mathbf{X D}_{133} \ldots \ldots \ldots \mathbf{H}_{187} \ldots \ldots \ldots \mathbf{R}_{204}$ YNLTFR $_{210}$. The two histidines and the aspartic acid are proposed to form the active site for interaction with $\mathrm{Fe}^{\mathrm{II}}$, whereas the first arginine is involved in the binding of the C-5 carboxylate of 2-oxoglutarate. These residues are highly conserved in the $\alpha$-KG-dependent oxygenases (Wei et al., 1996; Aas et al., 2003; Kurowski et al., 2003).
Three proteins, human $\mathrm{ABH} 2$ and $\mathrm{ABH} 3$ and bacterial AlkB differ with respect to substrate specificity. In contrast to $\mathrm{AlkB}$ and $\mathrm{ABH} 3, \mathrm{ABH} 2$ preferentially acts on double-stranded DNA and more effectively repair $1 \mathrm{meA}$, whereas $3 \mathrm{meC}$ is a preferable substrate for ABH3 (Duncan et al., 2002; Falnes et al., 2004).

Both AlkB and $\mathrm{ABH} 3$ remove 1meA and 3 meC from RNA as well. In an in vitro experimental system AlkB repairs different types of alkylated RNA including mRNA, tRNA, rRNA and viral tRNA. AlkB as well as ABH3 have been shown to reverse the effect of MMS treatment (chemical methylation of mRNA blocks translation) on luciferase mRNA. The proteins reactivate also methylated tRNA ${ }^{\text {Phe }}$ (Ougland et al., 2004). ABH3 acts with similar efficiency on DNA and RNA, whereas AlkB preferentially repairs DNA. This may indicate a greater importance of the repair of the more stable eukaryotic mRNA in comparison with the repair of prokaryotic mRNA (Aas et al., 2003). On the other hand, many tRNAs and rRNAs require 1meA and $3 \mathrm{meC}$ for correct folding and activity. The question remains then, whether and how the AlkB-related enzymes distinguish between the proper and aberrant methylation, and what is their role in these RNAs' modification under normal conditions. Another important question is whether a slow demethylation of tRNA and rRNA by enzymes of the AlkB family may be tolerated by the cell and restored by RNA methyltransferases (Ougland et al., 2004).

The subcellular localization of $\mathrm{hABH} 2$ and hABH3 has been examined by transfection experiments in HeLa cells. In non-S-phase cells hABH2 is homogenously distributed in the nucleoplasm, with a slightly higher concentration in nucleoli. In S phase it relocates to replication foci and colocalizes with PCNA, suggesting a role in the repair of newly synthesized DNA. hABH3 has been observed both in the nucleoplasm and cytoplasm and possibly is involved in mRNA repair (Aas et al., 2003).

$\mathrm{ABH} 2$ and $\mathrm{ABH} 3$ are not expressed equally in all human tissues. A high level of $\mathrm{ABH} 2$ mRNAs was observed in non proliferating liver tissue whereas the expression of hABH3 was high in the heart, liver, prostate and testis (Sedgwick et al., 2007). The $\mathrm{ABH} 3$ expression is elevated in prostate carcinomas and has been reported as prostate cancer antigen-1 (PCA-1). ABH3/PCA-1 has been proposed as a diagnostic marker of prostate cancer and suggested as possible therapeutic target (Konishi et al., 2005). Nevertheless, recent studies indicate a grater importance of hABH2 as a defense against toxic alkylation damage to DNA (Ringvoll et al., 2006). The ability of AlkB-like proteins to repair some lesions generated by anticancer chemotherapeutics (e.g. BCNU) may indicate their role in cancer therapy. 


\section{ALKYLATED DNA REPAIR IN CELLS DEFICIENT IN AlkB PROTEIN}

Damage to alkB greatly increases the sensitivity of bacteria to the cytotoxic action of MMS and diminishes the ability of reactivation of MMS-treated single-stranded phage DNA. It also markedly increases the level of MMS-induced $\operatorname{argE3} \rightarrow \mathrm{Arg}^{+}$reversion in E. coli argE3 alkB-, but only a slight elevation of $\mathrm{lac}^{-} \rightarrow$ $\mathrm{Lac}^{+}$reversion in E. coli F'lacZ $\mathrm{F}^{-}$(AlacZ CC101-CC106) strains has been observed (Yamamoto et al., 1978; Kataoka et al., 1983; Dinglay et al., 2000; Nieminuszczy et al., 2006a; 2006b). A deficiency in AlkB protein followed by an inability to repair $1 \mathrm{meA} / 3 \mathrm{meC}$ in DNA greatly increases the mutagenic potency of MMS. Interestingly, the resultant mutations are $u m u D C$-dependent (Nieminuszczy et al., 2006b).

MMS, apart of the Ada response, induces the SOS system that increases expression of over 40 genes involved in DNA recombination, repair, replication and mutagenesis (Fernandez De Henestrosa et al., 2000; Courcelle et al., 2001; Janion, 2001). Among these genes are $u m u D$ and $u m u C$, whose products are required for translesion synthesis. UmuC and posttranslationally modified UmuD (UmuD') form the UmuD' ${ }_{2}$-UmuC complex described as low fidelity DNA polymerase V (Pol V) (Fuchs et al., 2004; Goodman \& Woodgate, 2000; Reuven et al., 1999). The $3 \mathrm{meA}$ residues introduced by alkylating agents that arrest DNA replication are also an induction signal for the SOS response (Costa de Oliveira et al., 1987). Induction of the SOS system and expression of Pol V is a prerequisite for $60-70 \%$ of MMS-induced mutations occurring in wild type E. coli. These mutations are $\mathrm{AT} \rightarrow \mathrm{TA}$ transversions, whereas for the remaining $30-40 \% \mathrm{O}^{6} \mathrm{meG}$ residues are probably the premutagenic lesions that induce umuDC-independent GC $\rightarrow$ AT transitions (Grzesiuk \& Janion, 1994).

In alkB mutants the fraction of MMS-induced $u m u D C$-dependent mutations is even higher than in the wild type and equals $95-98 \%$ of $\mathrm{Arg}^{+}$revertants in an E. coli argE3 alkB strain (Nieminuszczy et al., 2006b). In such strains mutations are formed from $3 \mathrm{meC}$ residues and are umuDC-dependent. Of the two premutagenic lesions $\mathrm{O}^{6} \mathrm{meG}$ and $3 \mathrm{meC}$, only the latter requires Pol V-directed translesion synthesis to express mutations. Not long ago it has been shown that Pol V activity increases the level of mutations induced by $3 \mathrm{meC}$ and $1 \mathrm{meA}$ (Delaney \& Essigmann, 2004). Mutations specific for E. coli alkB- strains are due to GC $\rightarrow$ AT, GC $\rightarrow$ TA, and AT $\rightarrow$ TA base substitutions, and $-1 \mathrm{G}$ and $-2 \mathrm{CG}$ frameshifts (Dinglay et al., 2000; Nieminuszczy et al., 2006a, 2006b). Concluding, the MMS-induced mutagenesis in E. coli cells depends on the balance between the repair of the methylated bases in DNA provided by Ada response and the ex- pression of mutations due to Pol V activity induced as part of the SOS response.

In summary, finding the functions of bacterial $\mathrm{AlkB}$ and mammalian $\mathrm{ABH} 2$ and $\mathrm{ABH} 3$ proteins gives a new insight into the defense mechanisms protecting cells against mutagenic and cytotoxic effects of alkylation. The roles of ABH1 and ABH4-8 proteins remain unsolved.

\section{Acknowledgements}

This work was supported by the State Committee for Scientific Research (KBN, Poland) grant 0420/P04/2004/27.

\section{REFERENCES}

Aas PA, Otterlei M, Falnes PO, Vagbo CB, Skorpen F, Akbari M, Sundheim O, Bjoras M, Slupphaug G, Seeberg E, Krokan HE (2003) Human and bacterial oxidative demethylases repair alkylation damage in both RNA and DNA. Nature 421: 859-863.

Aravind L, Koonin EV (2001) The DNA-repair protein AlkB, EGL-9, and leprecan define new families of 2-oxoglutarate- and iron-dependent dioxygenases. Genome Biol 2: RESEARCH0007.

Arczewska KD, Kusmierek J (2007) Bacterial DNA repair genes and their eukaryotic homologues: 2. Role of bacterial mutator gene homologues in human disease. Overview of nucleotide pool sanitization and mismatch repair systems. Acta Biochim Polon 54: 435-457.

Barrows LR, Magee PN (1982) Nonenzymatic methylation of DNA by $S$-adenosylmethionine in vitro. Carcinogenesis 3: 349-531.

Becker K, Dosch J, Gregel CM, Martin BA, Kaina B (1996) Targeted expression of human $O^{6}$-methylguanine-DNA methyltransferase (MGMT) in transgenic mice protects against tumor initiation in two-stage skin carcinogenesis. Cancer Res 56: 3244-3249.

Bodell WJ, Singer B (1979) Influence of hydrogen bonding in DNA and polynucleotides on reaction of nitrogens and oxygens toward ethylnitrosourea. Biochemistry 18: 2860-2863.

Brennand J, Margison GP (1986) Expression in mammalian cells of a truncated Escherichia coli gene coding for O6alkylguanine alkyltransferase reduces the toxic effects of alkylating agents. Carcinogenesis 7: 2081-2084.

Chaney SG, Sancar A (1996) DNA repair: enzymatic mechanisms and relevance to drug response. J Natl Cancer Inst 88: 1346-1360.

Chen BJ, Carroll P, Samson L (1994) The Escherichia coli AlkB protein protects human cells against alkylationinduced toxicity. J Bacteriol 176: 6255-6261.

Costa de Oliveira R, Laval J, Boiteux S (1987) Induction of SOS and adaptive responses by alkylating agents in Escherichia coli mutants deficient in 3-methyladenineDNA glycosylase activities. Mutat Res 183: 11-20.

Courcelle J, Khodursky A, Peter B, Brown PO, Hanawalt PC (2001) Comparative gene expression profiles following UV exposure in wild-type and SOS-deficient Escherichia coli. Genetics 158: 41-64.

Daniels DS, Tainer JA (2000) Conserved structural motifs governing the stoichiometric repair of alkylated DNA 
by $\mathrm{O}^{6}$-alkylguanine-DNA alkyltransferase. Mutat Res 460: 151-163.

Daniels DS, Mol CD, Arvai AS, Kanugula S, Pegg AE, Tainer JA (2000) Active and alkylated human AGT structures: a novel zinc site, inhibitor and extrahelical base binding. EMBO J 19: 1719-1730.

Delaney JC, Essigmann JM (2004) Mutagenesis, genotoxicity, and repair of 1-methyladenine, 3-alkylcytosines, 1-methylguanine, and 3-methylthymine in alkB Escherichia coli. Proc Natl Acad Sci USA 101: 14051-14056.

Delaney JC, Smeester L, Wong C, Frick LE, Taghizadeh K, Wishnok JS, Drennan CL, Samson LD, Essigmann JM (2005) AlkB reverses etheno DNA lesions caused by lipid oxidation in vitro and in vivo. Nat Struct Mol Biol 12: $855-860$.

Dinglay S, Trewick SC, Lindahl T, Sedgwick B (2000) Defective processing of methylated single-stranded DNA by E. coli AlkB mutants. Genes Dev 14: 2097-2105.

Drablos F, Feyzi E, Aas PA, Vaagbo CB, Kavli B, Bratlie MS, Pena-Diaz J, Otterlei M, Slupphaug G, Krokan HE (2004) Alkylation damage in DNA and RNA-repair mechanisms and medical significance. DNA Repair (Amst) 3: 1389-1407.

Dumenco LL, Allay E, Norton K, Gerson SL (1993) The prevention of thymic lymphomas in transgenic mice by human O6-alkylguanine-DNA alkyltransferase. Science 259: 219-222.

Duncan T, Trewick SC, Koivisto P, Bates PA, Lindahl T, Sedgwick B (2002) Reversal of DNA alkylation damage by two human dioxygenases. Proc Natl Acad Sci USA 99: 16660-16665.

Falnes PO, Rognes T (2003) DNA repair by bacterial AlkB proteins. Res Microbiol 154: 531-538.

Falnes PO, Johansen RF, Seeberg E (2002) AlkB-mediated oxidative demethylation reverses DNA damage in Escherichia coli. Nature 419: 178-182.

Falnes PO, Bjoras M, Aas PA, Sundheim O, Seeberg E (2004) Substrate specificities of bacterial and human AlkB proteins. Nucleic Acids Res 32: 3456-3461.

Fernandez De Henestrosa AR, Ogi T, Aoyagi S, Chafin D, Hayes JJ, Ohmori H, Woodgate R (2000) Identification of additional genes belonging to the LexA regulon in Escherichia coli. Mol Microbiol 35: 1560-1572.

Frick LE, Delaney JC, Wong C, Drennan CL, Essigmann JM (2007) Alleviation of $1, N^{6}$-ethanoadenine genotoxicity by the Escherichia coli adaptive response protein AlkB. Proc Natl Acad Sci USA 104: 755-760.

Fuchs RP, Fujii S, Wagner J (2004) Properties and functions of Escherichia coli: Pol IV and Pol V. Adv Protein Chem 69: 229-264.

Garcia-Santos Mdel P, Calle E, Casado J (2001) Amino acid nitrosation products as alkylating agents. J Am Chem Soc 123: 7506-7510.

Gerson SL (2002) Clinical relevance of MGMT in the treatment of cancer. J Clin Oncol 20: 2388-2399.

Goodman MF, Woodgate R (2000) The biochemical basis and in vivo regulation of SOS-induced mutagenesis promoted by Escherichia coli DNA polymerase V (UmuD'2C). Cold Spring Harb Symp Quant Biol 65: 3140.

Goodwin KD, Tokarczyk R, Stephens FC, Saltzman ES (2005) Description of toluene inhibition of methyl bromide biodegradation in seawater and isolation of a marine toluene oxidizer that degrades methyl bromide. Appl Environ Microbiol 71: 3495-3503.

Grzesiuk E, Janion C (1994) The frequency of MMS-induced, umuDC-dependent, mutations declines during starvation in Escherichia coli. Mol Gen Genet 245: 486492.
Hamilton JT, McRoberts WC, Keppler F, Kalin RM, Harper DB (2003) Chloride methylation by plant pectin: an efficient environmentally significant process. Science 301: 206-209.

Harris AL, Karran P, Lindahl T (1983) O6-MethylguanineDNA methyltransferase of human lymphoid cells: structural and kinetic properties and absence in repairdeficient cells. Cancer Res 43: 3247-3252.

He C, Verdine GL (2002) Trapping distinct structural states of a protein/DNA interaction through disulfide crosslinking. Chem Biol 9: 1297-1303.

He C, Wei H, Verdine GL (2003) Converting the sacrificial DNA repair protein $\mathrm{N}$-Ada into a catalytic methyl phosphotriester repair enzyme. J Am Chem Soc 125: 1450-1451.

Hecht SS (2002) Human urinary carcinogen metabolites: biomarkers for investigating tobacco and cancer. Carcinogenesis 23: 907-922.

Hickman MJ, Samson LD (1999) Role of DNA mismatch repair and p53 in signaling induction of apoptosis by alkylating agents. Proc Natl Acad Sci USA 96: 1076410769.

Hurley LH (2002) DNA and its associated processes as targets for cancer therapy. Nat Rev Cancer 2: 188-200.

Janion C (2001) Some aspects of the SOS response system - a critical survey. Acta Biochim Polon 48: 599-610.

Kataoka H, Yamamoto Y, Sekiguchi M (1983) A new gene (alkB) of Escherichia coli that controls sensitivity to methyl methane sulfonate. J Bacteriol 153: 1301-1307.

Kataoka H, Hall J, Karran P (1986) Complementation of sensitivity to alkylating agents in Escherichia coli and Chinese hamster ovary cells by expression of a cloned bacterial DNA repair gene. EMBO J 5: 3195-3200.

Katayanagi K, Miyagawa M, Matsushima M, Ishikawa M, Kanaya S, Ikehara M, Matsuzaki T, Morikawa K (1990) Three-dimensional structure of ribonuclease $\mathrm{H}$ from $E$. coli. Nature 347: 306-309.

Koike G, Maki H, Takeya H, Hayakawa H, Sekiguchi M (1990) Purification, structure, and biochemical properties of human $\mathrm{O}^{6}$-methylguanine-DNA methyltransferase. J Biol Chem 265: 14754-14762.

Koivisto P, Duncan T, Lindahl T, Sedgwick B (2003) Minimal methylated substrate and extended substrate range of Escherichia coli AlkB protein, a 1-methyladenineDNA dioxygenase. J Biol Chem 278: 44348-44354.

Kondo H, Nakabeppu Y, Kataoka H, Kuhara S, Kawabata S, Sekiguchi M (1986) Structure and expression of the alkB gene of Escherichia coli related to the repair of alkylated DNA. J Biol Chem 261: 15772-15777.

Konishi N, Nakamura M, Ishida E, Shimada K, Mitsui E, Yoshikawa R, Yamamoto H, Tsujikawa K (2005) High expression of a new marker PCA-1 in human prostate carcinoma. Clin Cancer Res 11: 5090-5097.

Krwawicz J, Arczewska KD, Speina E, Maciejewska A, Grzesiuk E (2007) Bacterial DNA repair genes and their eukaryotic homologues: 1. Mutations in genes involved in base excision repair (BER) and DNA-end processors and their implication in mutagenesis and human disease. Acta Biochim Polon 54: 413-434.

Kurowski MA, Bhagwat AS, Papaj G, Bujnicki JM (2003) Phylogenomic identification of five new human homologs of the DNA repair enzyme AlkB. BMC Genomics 4: 48 .

Landini P, Volkert MR (2000) Regulatory responses of the adaptive response to alkylation damage: a simple regulon with complex regulatory features. J Bacteriol 182: 6543-6549. 
Landini P, Hajec LI, Volkert MR (1994) Structure and transcriptional regulation of the Escherichia coli adaptive response gene aidB. J Bacteriol 176: 6583-6589.

Lawley PD, Brookes P (1963) Further studies on the alkylation of nucleic acids and their constituent nucleotides. Biochem J 89: 127-138.

Lindahl T, Sedgwick B, Sekiguchi M, Nakabeppu Y (1988) Regulation and expression of the adaptive response to alkylating agents. Annu Rev Biochem 57: 133-157.

Lu SC (2000) S-Adenosylmethionine. Int J Biochem Cell Biol 32: 391-395.

Lutz WK (1990) Endogenous genotoxic agents and processes as a basis of spontaneous carcinogenesis. Mutat Res 238: 287-295.

Maddukuri L, Dudzińska D, Tudek B (2007) Bacterial DNA repair genes and their eukaryotic homologues: 4 . The role of nucleotide excision DNA repair (NER) system in mammalian cells. Acta Biochim Polon 54: 469-482.

Middleton MR, Kelly J, Thatcher N, Donnelly DJ, McElhinney RS, McMurry TB, McCormick JE, Margison GP (2000) O(6)-(4-bromothenyl)guanine improves the therapeutic index of temozolomide against A375M melanoma xenografts. Int J Cancer 85: 248-252.

Mishina Y, Yang CG, He C (2005) Direct repair of the exocyclic DNA adduct $1, N^{6}$-ethenoadenine by the DNA repair AlkB proteins. J Am Chem Soc 127: 14594-14595.

Moore MH, Gulbis JM, Dodson EJ, Demple B, Moody PC (1994) Crystal structure of a suicidal DNA repair protein: the Ada O6-methylguanine-DNA methyltransferase from E. coli. EMBO J 13: 1495-1501.

Myers LC, Terranova MP, Nash HM, Markus MA, Verdine GL (1992) Zinc binding by the methylation signaling domain of the Escherichia coli Ada protein. Biochemistry 31: 4541-4547.

Nakatsuru Y, Matsukuma S, Nemoto N, Sugano H, Sekiguchi M, Ishikawa T (1993) O6-methylguanine-DNA methyltransferase protects against nitrosamine-induced hepatocarcinogenesis. Proc Natl Acad Sci USA 90: 64686472.

Nieminuszczy J, Janion C, Grzesiuk E (2006a) Mutator specificity of Escherichia coli alkB117 allele. Acta Biochim Polon 53: 425-428.

Nieminuszczy J, Sikora A, Wrzesinski M, Janion C, Grzesiuk E (2006b) AlkB dioxygenase in preventing MMSinduced mutagenesis in Escherichia coli: effect of Pol V and AlkA proteins. DNA Repair (Amst) 5: 181-188.

Nowosielska A (2007) Bacterial DNA repair genes and their eukaryotic homologues: 5 . The role of recombination in DNA repair and genome stability. Acta Biochim Polon 54: 483-494.

Ougland R, Zhang CM, Liiv A, Johansen RF, Seeberg E, Hou YM, Remme J, Falnes PO (2004) AlkB restores the biological function of mRNA and tRNA inactivated by chemical methylation. Mol Cell 16: 107-116.

Potter PM, Wilkinson MC, Fitton J, Carr FJ, Brennand J, Cooper DP, Margison GP (1987) Characterisation and nucleotide sequence of ogt, the O6-alkylguanine-DNAalkyltransferase gene of E. coli. Nucleic Acids Res 15: 9177-9193.

Rebeck GW, Coons S, Carroll P, Samson L (1988) A second DNA methyltransferase repair enzyme in Escherichia coli. Proc Natl Acad Sci USA 85: 3039-3043.

Reuven NB, Arad G, Maor-Shoshani A, Livneh Z (1999) The mutagenesis protein UmuC is a DNA polymerase activated by UmuD', RecA, and SSB and is specialized for translesion replication. J Biol Chem 274: 3176331766.

Ringvoll J, Nordstrand LM, Vagbo CB, Talstad V, Reite K, Aas PA, Lauritzen KH, Liabakk NB, Bjork A, Doughty
RW, Falnes PO, Krokan HE, Klungland A (2006) Repair deficient mice reveal $\mathrm{mABH} 2$ as the primary oxidative demethylase for repairing $1 \mathrm{meA}$ and $3 \mathrm{meC}$ lesions in DNA. EMBO J 25: 2189-2198.

Rohankhedkar MS, Mulrooney SB, Wedemeyer WJ, Hausinger RP (2006) The AidB component of the Escherichia coli adaptive response to alkylating agents is a flavincontaining, DNA-binding protein. J Bacteriol 188: 223230.

Rydberg B, Lindahl T (1982) Nonenzymatic methylation of DNA by the intracellular methyl group donor S-adenosyl-L-methionine is a potentially mutagenic reaction. EMBO J 1: 211-216.

Saget BM, Walker GC (1994) The Ada protein acts as both a positive and a negative modulator of Escherichia coli's response to methylating agents. Proc Natl Acad Sci USA 91: 9730-9734.

Sedgwick B, Vaughan P (1991) Widespread adaptive response against environmental methylating agents in microorganisms. Mutat Res 250: 211-221.

Sedgwick B, Robins P, Totty N, Lindahl T (1988) Functional domains and methyl acceptor sites of the Escherichia coli ada protein. J Biol Chem 263: 4430-4433.

Sedgwick B, Bates PA, Paik J, Jacobs SC, Lindahl T (2007) Repair of alkylated DNA: recent advances. DNA Repair (Amst) 6: 429-442.

Shevell DE, Abou-Zamzam AM, Demple B, Walker GC (1988) Construction of an Escherichia coli K-12 ada deletion by gene replacement in a recD strain reveals a second methyltransferase that repairs alkylated DNA. $J$ Bacteriol 170: 3294-3296.

Shuker DE, Margison GP (1997) Nitrosated glycine derivatives as a potential source of O6-methylguanine in DNA. Cancer Res 57: 366-369.

Singer B (1976) All oxygens in nucleic acids react with carcinogenic ethylating agents. Nature 264: 333-339.

Teo I, Sedgwick B, Demple B, Li B, Lindahl T (1984) Induction of resistance to alkylating agents in E. coli: the ada+ gene product serves both as a regulatory protein and as an enzyme for repair of mutagenic damage. EMBO J 3: 2151-2117.

Tong WP, Kirk MC, Ludlum DB (1982) Formation of the cross-link 1-[N3-deoxycytidyl), 2-[N1deoxyguanosinyl]ethane in DNA treated with $\mathrm{N}, \mathrm{N}^{\prime}-$ bis(2-chloroethyl)-N-nitrosourea. Cancer Res 42: 31023105.

Trewick SC, Henshaw TF, Hausinger RP, Lindahl T, Sedgwick B (2002) Oxidative demethylation by Escherichia coli AlkB directly reverts DNA base damage. Nature 419: 174-178.

Tyroller S, Zwickenpflug W, Richter E (2002) New sources of dietary myosmine uptake from cereals, fruits, vegetables, and milk. I Agric Food Chem 50: 4909-4915.

Wei YF, Carter KC, Wang RP, Shell BK (1996) Molecular cloning and functional analysis of a human cDNA encoding an Escherichia coli AlkB homolog, a protein involved in DNA alkylation damage repair. Nucleic Acids Res 24: 931-937.

Wibley JE, Pegg AE, Moody PC (2000) Crystal structure of the human $\mathrm{O}(6)$-alkylguanine-DNA alkyltransferase. Nucleic Acids Res 28: 393-401.

Yamamoto Y, Katsuki M, Sekiguchi M, Otsuji N (1978) Escherichia coli gene that controls sensitivity to alkylating agents. J Bacteriol 135: 144-152.

Yang W, Hendrickson WA, Crouch RJ, Satow Y (1990) Structure of ribonuclease $\mathrm{H}$ phased at $2 \mathrm{~A}$ resolution by MAD analysis of the selenomethionyl protein. Science 249: 1398-13405. 